Per Edgar Kokkvold

Skribent og leder av Kringkastingsrådet

Foto: Birgit Dannenberg

\title{
De fatale feil
}

Det er menneskelig å feile. I så måte er også leger meget menneskelige.

«Doctors bury their mistakes. Lawyers hang them. But journalists put theirs on the front page.»

Det er 50 år siden jeg første gang kom over dette sitatet, av ukjent opphavsmann, i Anthony Sampsons klassiske statsvitenskapelige anatomi, Anatomy of Britain. $i$ innledningen til kapitlet om pressen.

Juristene har etter hvert fått mindre å svare for. Ingen er henrettet ved dom i Norge siden 1948. De to siste henrettelsene på De britiske øyer fant sted 13. august 1964, ved hengning. Albert Pierrepoint, den nest siste og mest kjente av de britiske bødlene, trakk seg fra virksomheten i 1956. etter en honorarkrangel med statsmakten. Som 11-åring hadde han i en skolestil skrevet at hans høyeste ønske var å bli offisiell bøddel når han ble stor. Og det ble han. Da han trakk seg, hadde han rukket å henrette 433 menn og 17 kvinner. De aller fleste av dem skyldige. Får vi tro.

Men Pierrepoint kan likevel ha fått moralske anfektelser. Senere i livet åpnet han sin egen pub. Over baren hengte han opp et skilt hvor det sto «No Hanging Round the Bar».

De fleste land har i dag avskaffet dødsstraffen, men den praktiseres, ifølge Amnesty, fortsatt i 57 land.

Hva så med journalistene?

I få bransjer blir det begått flere feil. Nesten alle medier innholder feil, så å si hver eneste dag. De fleste er bagatellmessige og går ikke ut over andre enn mediene selv. Men noen er alvorlige og kan ramme enkeltmennesker så kraftig at de finner det vanskelig å leve videre. Og det gjelder ikke bare når et medium har feilet, men også når det utelukkende har gjort jobben sin: satt søkelyset inn i mørke rom og avdekket kritikkverdige forhold, innenfor akseptable presseetiske normer.

Undersøkelser har vist at de som får problemer med rettsvesenet, oppfatter det som en større belastning å bli omtalt med navn og bilde i mediene enn å bli varetektsfengslet, siktet, tiltalt og dømt. Også derfor er det viktig at mediene i sitt arbeid ikke påfører mennesker unødige lidelser og er nøye med å rette og beklage når man gjør feil eller begår urett mot enkeltmennesker

Derimot har jeg vanskeligere for å forstå at mennesker hisser seg så veldig opp når pressen en sjelden gang kommer i skade for å publisere en vakker nekrolog mens den omtalte lever i beste velgående. Hvorfor kan man ikke bare glede seg over omtalen, eller gjøre som maleren som ble så inspirert av sin egen nekrolog at han etterpå malte bedre enn noen gang?

Jeg har ikke hatt nevneverdig profesjonell kontakt med medisinere. Det kan ha sammenheng med frykt for at legevitenskapen nå er så høyt utviklet at leger ikke lenger klarer å erklære noe menneske for friskt. Jeg var i alle fall 68 år før jeg måtte oppsøke lege og svelge min første reseptbelagte pille. Men jeg leser aviser, og selv om jeg etter beste evne forsøker å unngå helserelatert stoff, har jeg selvfølgelig fått med meg at også leger gjør fatale feil, ja at de ikke helt sjelden også «begraver» sine feiltakelser

I gamle dager ble de nok ofte begravet i stillhet, uten at verken pårørende eller allmennhet var informert om hva som lå bak. I dag er det annerledes. Det er en helt annen åpenhet enn tidligere når leger begår feil. Kravene til varsling er mange og strenge, og må være det. Legetabber påkaller dessuten medienes oppmerksomhet. Det går ikke upåaktet hen når en operasjonslege glemmer en saks i pasientens buk, amputerer feil fot eller fjerner høyre bryst når det var det venstre som skulle fjernes, eller kanskje ingen av dem.

Hvert år dør det et betydelig antall mennesker i Norge som resultat av tabber og feilbehandlinger i helsetjenesten. Slike tragiske dødsfall vil aldri forsvinne - heller ikke helsepersonell vil noen gang slutte å feile - men tallene kan selvfølgelig reduseres, gjennom økt skolering, ny viten og godt arbeid.

Mange har sterke beretninger fra møter med leger og helsestell. Jeg har ikke stort å melde på det området. Min sterkeste medisinske opplevelse stammer fra et apotek i London, der jeg for noen år siden kjøpte en eske reseptfrie sugetabletter mot sår hals.

På baksiden av esken sto det: «Denne medisin kan forårsake høyt blodtrykk, hjertebank, altfor langsomme eller altfor raske hjerteslag, hodepine, forstoppelse, urineringsproblemer, frykt, rastløshet, svimmelhet, kvalme, oppkast, overfølsomhet, manglende appetitt, skjelving, blåmerker og allergiske reaksjoner. Dersom det skulle skje noe utover dette, vennligst snakk med Deres apoteker eller lege.»

For å si det slik: Jeg hadde medisin, men rørte den ei!

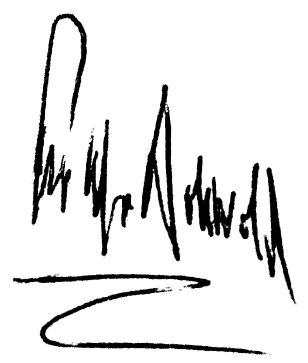

